\title{
EFFECT OF APPLIED ORGANIC MANURE AND FOLIAR SPRAY WITH ANTIOXIDANTS ON GROWTH, YIELD AND CHEMICAL CONSTITUENTS OF CARAWAY PLANT
}

\author{
Sawsan, A. Saif El-Yazal *and Essam, G. Somida** \\ * Dep. of Soil Sci., Fac. of Agic. Fayoum, Univ., Egypt \\ ** Dep. of Hort., Ministry of Education Fayoum, Egypt
}

\section{ABSTRACT}

A filed experiments was carried out during two successive seasons of 2005/2006and 2006/2007 to study the effect of farmyard manure( FYM) at rates $0,15,25$ and $35 \mathrm{~m}^{3} /$ fed. or foliar spray with applied of antioxidant (ascorbic acid)at rates $0,5,10$ and $15 \mathrm{mM}$./L, either alone or in combination with each other on growth, yield and some chemical constituents of caraway (Carum carvi L.,) plants. The obtained results indicated that, all growth parameters i.e., plant height, number of branches, number of compound umbels /plant; yield and its components i.e. fruits yield per plant or feddan, fruit oil \%, fruit oil yield per plant and, or feddan, as well as some chemical constituents i.e. chlorophyll a, $\mathrm{b}$, total caroteniods, nitrogen, phosphorous and potassium $\%$ in herb and total carbohydrates, total nitrogen and total protein $\%$ in fruits were significantly increased as a result of applied farmyard manure and ascorbic acid either added alone or in combination with each other. The best results were obtained by applying the middle rates of FYM and high $\left(25 \& 35 \mathrm{~m}^{3} / \mathrm{fed}\right)$ and ascorbic acid $10 \& 15 \mathrm{mM}$. /L) either added alone or in combined with each other, with insignificant differences. These treatments were statistically almost equal for producing significant values than the other treatments in the two studied seasons. From the economical point of view, the maximum increments in all studied growth parameters and chemical constituents as well as yield and its component were obtained by fertilization with farmyard manure at rate $25 \mathrm{~m}^{3} / \mathrm{fed}$. combined with foliar spray by ascorbic acid at rate $10 \mathrm{mM} . / \mathrm{L}$ under the prevailing conditions of the current expermint.

Key words: Caraway (Carum carvi L.), farmyard manure "FYM', antioxidants, ascorbic acid, "growth parameters and chemical constituents.

\section{INTRODUCTION}

Caraway (Carum carvi L.,) is a popular, medicinal spices plant of Lamiaceae and is well known for it's highly aromatic and ingredient of coughrelieving, stomachache, diuretic, carminative tea blends used in food industries for spicing canned drinks. It is most important species being utilized as a source of essential oil.

The organic matter content of Egyptian soil is usually less than $2 \%$ in cultivate area. Frequent the application of organic manure are necessary to maintain soil fertility and to provide the growing plants with their nutritional requirements without having an undesirable impact on the environmental condition. Organic fertilization also provides a means for alleviating the problem of chemical residues in the exporting market. Stimulation growth characters by fertilized with organic manure was observed by Aly (1999) on Nigella sativa L.(black cumin) plants; Mohamed and Matter (2001) and Somida, (2002) on Tagetes minuta L.; Abd El-Raouf (2001), El-Gendy et al.,

Fayoum J. Agric. Res. \& Dev., Vol.22, No.2, July, 2008 
2001), El-Yazal, et al., (2005) and Matter and Somida (2006)on Ocimum basilicum L., and Mohamed (2006) on Hibiscus esculenta L plants.

Recently, this is a widespread use of natural and safety substances such as antioxidants, particularly ascorbic acid, for enhancing the health, growth and productivity of many crops. Since, antioxidants have synergistic effect on growth, flowering, yield and chemical composition under favorable and unfavorable environmental condition, due to these compounds as non enzymatic material and have a beneficial effect on catching the free radical or the active oxygen species namely singlet oxygen, super oxide caraway, hydrogen peroxide, hydroxyl radicals and ozone that oxygen that producing during photosynthesis and respiration process (Zhang and Klessing, 1997). Leaving these free radicals without chelating or catching leads to lipids oxidation and the loss of plasma membrane permeability and the death of cell within plant tissues. They also have an auxin action (Prusky, 1988 and Raskin, 1992). The beneficial effect of antioxidants on growth ,yield and some chemical constituents of several plants was reported by several workers such as Reda et al. (1977)on Ammi visnaga L. ; El-Kholy and Salem (1980)on Matricaria chamomilla L.; Arulniozhiyan and Pappaiah (1989) on marigold (Calendula officinalis L.); Abd-El-Hamid et al. (1994)on Opuntia (ficusindica); Dobariya and Mehta (1995) on Indian mustard (Brassica juncea L.); Rai (1997) on Bauhinia purpurea L.; Tarraf et al. (1999) on lemongrass (Cymbopogon citrates L.); El-Khayat (2001) on roselle (Hibiscus sabdariffa L.); El-Fawakhry and El- Tayeb (2003) on Dendranthema grandiflorum; Taha (2005) on tuberose (Polianthes tuberose L.) plants; Rady (2006) on sunflower (Helianthus annuиa L.); and El-Yazal (2007) on onion (Allium cepa L.) plants.

This study was conducted with the aim of studying the effect of organic manure (farmyard manure) either alone or in combination with antioxidants (ascorbic acid) on the growth, oil yield and some chemical components of caraway (Carum carvi L.,) plants.

\section{MATERIAL AND METHODS}

The present investigation was carried out during the two successive seasons of 2005/2006 and 2006/2007 at Sennouris, Fayoum Governorate. Before planting the most important physical and chemical properties of the selected soil were determined (Table 1) according to Wilde et al. (1985). Farmyard manure was obtained from private farm in Sennouris, El-Fayoum Governorate. Also, some chemical properties of the used farmyard manure are shown in Table (1).

Seeds of caraway (Carum carvi L.,) were obtained from the Research Center of Medicinal and Aromatic plants in Giza, Egypt in the two successive seasons of the study. On October $15^{\text {th }}$ of each season, seeds were sown in hills $30 \mathrm{~cm}$ apart $(4 \mathrm{seeds} / \mathrm{hill})$ each plot $(2.4 \times 2 \mathrm{~m})$ contained 4 rows $(60 \mathrm{~cm}$ wide with $3 \mathrm{~m}$ length). Each plot contained 26 hills and plants were thinned to two plants per hill after 5 weeks from planting. The experimental design used was factorial experiment in randomized complete block with four replications. Farmyard manure (FYM) at the rates $0,15,25$ and $35 \mathrm{~m}^{3} / \mathrm{fed}$., were applied at one dose and incorporated with the soil at two weeks before sown. The plants were sprayed with tap water (as a control) or ascorbic acid at rates of $(5,10$ and $15 \mathrm{mM}$ ). Few drops of Triton B as a wetting agent at $0.1 \%$ were added to the spraying solution as a surfactant. The foliar applications were carried out at 30 and 60 days after sowing.

Fayoum J. Agric. Res. \& Dev., Vol.22, No.2, July, 2008 
EFFECT OF APPLIED ORGANIC MANURE AND FOLIAR ......

Table (1): The physical and chemical of used soil and organic fertilizers before planting in both seasons.

\begin{tabular}{|c|c|c|c|c|c|}
\hline \multirow{2}{*}{\multicolumn{2}{|c|}{ Properties }} & \multicolumn{2}{|c|}{ Soil } & \multicolumn{2}{|c|}{ Farmyard manure } \\
\hline & & $\mathbf{1}^{\mathrm{st}}$ & $2^{\text {nd }}$ & $1^{\text {st }}$ & $2^{\text {nd }}$ \\
\hline \multicolumn{2}{|l|}{ Sand \% } & 44.90 & 44.95 & - & - \\
\hline \multicolumn{2}{|l|}{ Silt \% } & 30.28 & 30.21 & - & - \\
\hline \multicolumn{2}{|l|}{ Clay \% } & 24.82 & 24.84 & - & - \\
\hline \multicolumn{2}{|c|}{ Texture grade } & Loam & Loam & - & - \\
\hline \multicolumn{2}{|c|}{ Organic matter\% } & 1.70 & 1.76 & 33.28 & 35.29 \\
\hline \multicolumn{2}{|l|}{$\mathrm{pH}$} & 7.56 & 7.50 & 6.60 & 6.68 \\
\hline \multicolumn{2}{|l|}{$\mathrm{EC}, \mathrm{dS} / \mathrm{m}$} & 4.51 & 4.57 & 7.20 & 7.28 \\
\hline \multicolumn{2}{|l|}{ Total N \% } & 0.083 & 0.089 & 1.38 & 1.43 \\
\hline \multirow{6}{*}{$\begin{array}{c}\text { Available } \\
\text { nutrients } \\
\text { (mg/kg ) }\end{array}$} & $\mathrm{P}$ & 7.03 & 7.12 & 38.8 & 38.5 \\
\hline & $\mathrm{K}$ & 460 & 465 & 733 & 735 \\
\hline & $\mathrm{Zn}$ & 1.71 & 1.78 & 162 & 166 \\
\hline & $\mathrm{Mn}$ & 2.90 & 2.99 & 125 & 120 \\
\hline & $\mathrm{Cu}$ & 1.22 & 1.28 & 22.80 & 22.84 \\
\hline & $\mathrm{Fe}$ & 6.60 & 6.67 & 953 & 950 \\
\hline
\end{tabular}

1:2.5 (soil) 1:10 (FYM) solid material : water suspension

\section{Data recorded:-}

\section{Growth parameters:}

Different growth parameters i.e. plant height $(\mathrm{cm})$, number of branches, number of compound umbels/plants, were determined at the age of 120 days (flowering 25\%).

\section{Yield and its components:}

At harvest stage (at the age of 180 days) fruits yield per plant (g), per feddan $(\mathrm{kg})$ and fruit oil \% were determined

\section{Chemical constituents:}

The following chemical constituents were determined in leaves at the age of 120 days and in fruits at harvest (180 days).

Photosynthetic pigments: chlorophyll $\mathrm{a}, \mathrm{b}$ and total caroteniods were extracted from fresh leaves by acetone $(80 \%)$ then, their concentrations were determined as $\mathrm{mg} / 100 \mathrm{~g}$ fresh weight according to Welburn and Lichtenthaler (1984), Total carbohydrates( $\mathrm{mg} / \mathrm{g}$ dry weight) were determined calorimetrically by using phenol-sulphuric acid reagent according to the method described by Herbert et al. (1971).

Nitrogen $\%$, in leaves and fruits was determined according to micro Kjeldahl as described by A.O.A.C. (1995), and protein percentage in fruits was calculated by (nitrogen \% x 6.25), phosphorus \% was determined according to A.O.A.C. (1995), potassium was determined by Flame Photometer, Parkin-Elmer model 52 according to the method described by Page et al. (1982).

Essential oil in the fruits (crushed) was extracted by water distillation, and then dried over anhydrous sodium sulphate and determined according to Gad et al. (1963) and recorded as oil \%, then oil yield per plant and per feddan were calculated. 


\section{Statistical analysis:}

The experiment was in a complete randomized block design with 16 treatment and 4 replicates for each treatment. Results were statistically analyzed using the L.S.D. at probability level of 5\% for comparisons (Gomes and Gomes 1983).

RESULTS

A - Growth characteristics:

1 - Plant height and number of branches:

Data in Table (2) clearly show that the application of different rates of farmyard manure significantly increased plant height and number of branches, especially at the medium $\left(25 \mathrm{~m}^{3} / \mathrm{fed}\right)$ and highest rates $\left(35 \mathrm{~m}^{3} / \mathrm{fed}\right.$.). These increases reached 6.94 and $7.88 \%$ in the first season and 8.32 and $9.11 \%$ in the second one, respectively for plant height. The corresponding values for number of branches were 41.04 and $43.92 \%$ in the first one, and 41.98 and $45.49 \%$ over the unfertilized plants in the second one respectively. In the meantime, both medium $\left(25 \mathrm{~m}^{3} / \mathrm{fed}\right)$. and highest rates $\left(35 \mathrm{~m}^{3} / \mathrm{fed}\right)$. statistically, were achieved in significant differences for plant height and number of branches than the low rate $15 \mathrm{~m}^{3} / \mathrm{fed}$. and the control in the two experimental seasons. From the economical side, the highest values were obtained when Caraway plants received farmyard manure at rate $25 \mathrm{~m}^{3} / \mathrm{fed}$.,

Concerning the effect of ascorbic acid on plant height and number of branches, the data in Table (2) indicated that all rates of ascorbic acid significantly increased plant height and number of branches as compared with the control plants in both seasons. The best results were obtained by medium and highest rates (i.e., 10 and $15 \mathrm{mM} / \mathrm{L}$. respectively.) which recorded 8.12 and $8.84 \%$ in the first season and 8.73 and $9.58 \%$ in the second ones for plant height; and 47.31 and $50.14 \%$ in the first season and 42.72 and $45.29 \%$ in the second ones for number of branches respectively, over the control plants. On the other hand both treatments statistically, were achieved in significant differences increase in plant height and number of branches.

A combination between farmyard manure and ascorbic acid gave the better results than the solely treatments or untreated plants. The most effective treatments which gave the tallest plants and higher numbers of branches were due to the use of high rate of organic manure combined with high rate of ascorbic acid treatments in both studied seasons.

\section{2-Number of compound umbels/plants and fruits yield per plant (g) and per feddan (kg).}

The obtained data in Table (2) show clearly that number of compound umbels/plants, fruits yield per plant and per feddan of caraway plants were gradually and significantly increased with increasing the rate of farmyard manure up to $35 \mathrm{~m}^{3} / \mathrm{fed}$.in both seasons as compared to the control plants. Both the medium $\left(25 \mathrm{~m}^{3} / \mathrm{fed}\right)$ and highest rates $\left(35 \mathrm{~m}^{3} / \mathrm{fed}\right)$.were statistically achieved in significant increases than the other treatments. The increases were recorded 46.22 and $48.57 \%$ in the first one and 46.41 and $51.79 \%$ in the second one for number of compound umbels/plants; 24.06 and $25.00 \%$ in the first season and 23.70 and $24.65 \%$ in the second season for fruits yield per plant and feddan, respectively, over the control plants. From the economical side, the highest values were obtained when Caraway plants received farmyard manure (FYM) at the rate $25 \mathrm{~m}^{3} / \mathrm{fed}$.,

Fayoum J. Agric. Res. \& Dev., Vol.22, No.2, July, 2008 
Fayoum J. Agric. Res. \& Dev., Vol.22, No.2, July, 2008 
Regarding the effect of ascorbic acid application, it was clearly show that number of compound umbels /plants, fruits yield per plant and, feddan of caraway plants were also gradually increased by increasing the rate of ascorbic acid. The highest increase of number of compound umbels /plants, fruits yield per plant and feddan of caraway plants were obtained by using ascorbic acid at the rates of 10 and $15 \mathrm{mM} . / \mathrm{L}$. which recorded 46.75 and $49.77 \%$ in the first season and 40.69 and $43.21 \%$ in the second one for number of compound umbels/plants; 28.56 and $28.99 \%$ in the first season and 27.04 and $27.15 \%$ in the second one for fruits yield per plant and feddan, respectively, over the control plants.

The interaction between the organic manure fertilization and ascorbic acid treatments was significant for the number of compound umbels /plants, fruits yield per plant and, feddan of caraway plants in the two seasons as compared with the control. The maximum increase was obtained by the treatment $35 \mathrm{~m}^{3} \mathrm{FYM} /$ fed plus $15 \mathrm{mM}$ ascorbic acid./L which recorded 152.93 and $147.97 \%$ for number of compound umbels /plants and 95.24 and $96.37 \%$ for fruits yield per plant and feddan respectively over the control plants in the first and the second seasons, respectively. But the four combinations (M2+A2 or $\mathrm{M} 2+\mathrm{A} 3$ or $\mathrm{M} 3+\mathrm{A} 2$ or $\mathrm{M} 3+\mathrm{A} 3$ ) were, statistically achieved insignificant differences for number of compound umbels/plants, fruits yield per plant and feddan in the two studied seasons, as show in Table (2).

\section{3- Oil yield:}

Data in Table (3) show clearly that oil percentage per plant and oil yields per plant and feddan of caraway plants were gradually and significantly increased with increasing farmyard rates up to $35 \mathrm{~m}^{3} / \mathrm{fed}$.,in both studied seasons as compared to the control plants. Both the medium rate $\left(25 \mathrm{~m}^{3} / \mathrm{fed}\right)$ and highest rates $\left(35 \mathrm{~m}^{3} / \mathrm{fed}\right)$ were statistically, achieved in significant increases than the other treatments .The increases reached about 8.13 and 9.01 $\%$ in the first season and 7.70 and $8.57 \%$ in the second one for oil percentage per plant, 34.00 and $36.05 \%$ in the first season and 32.99 and $35.05 \%$ in the second one for oil yield /plant and oil yields per feddan respectively, as compared to the control plants.

Regarding the effect of ascorbic acid, it was clearly show that oil percentage per plant and oil yields per feddan of caraway plants were gradually increased by increasing the rates of ascorbic acid. The highest increase of oil percentage per plant and oil yields per feddan were obtained by used of both rates 10 and $15 \mathrm{mM} / \mathrm{L}$, with insignificant differences in the two seasons, however recorded 5.67 and $6.05 \%$ in the first season and 5.06 and $5.42 \%$ in the second one for oil percentage per plants and 35.53 and $36.48 \%$ in the first season and 33.02 and $33.60 \%$ in the second one for oil yield per plant and per feddan, respectively, over the control plants.

The interaction between the organic manure fertilization and ascorbic acid treatments was significant for increasing oil percentage per plant and oil yields per plant and per feddan as compared with the control in the two studied seasons. The maximum increase in the experimental was obtained by the use of $35 \mathrm{~m}^{3} \mathrm{FYM} /$ fed from organic manure plus $15 \mathrm{mM}$ ascorbic acid./L, which recorded 15.34 and $15.04 \%$ for oil percentage per plant and 125.24 and $125.98 \%$ for oil yields per feddan over the control plants in ether and second seasons respectively.

Fayoum J. Agric. Res. \& Dev., Vol.22, No.2, July, 2008 
Fayoum J. Agric. Res. \& Dev., Vol.22, No.2, July, 2008 


\section{B- Chemical constituents:-}

\section{1- Pigments:}

Data recorded in Table (3) clearly show in the two growing seasons that, farmyard fertilization had a simulative effect on chemical constituents of caraway plants. Photosynthetic pigments represented by chlorophyll a, b and caroteniods were gradually increased with increasing the rate of farmyard used. The best results were obtained with the medium $\left(25 \mathrm{~m}^{3} / \mathrm{fed}\right)$ and highest rates $\left(35 \mathrm{~m}^{3} / \mathrm{fed}\right)$. of farmyard manure, with insignificant between them. At the first season the corresponding increments over the control recorded 9.32 and $10.69 \%$ for chlorophyll. a; 13.42 and $14.42 \%$ for chlorophyll $b$ and 20.29 and $23.41 \%$ for caroteniods, as respectively compared to the untreated plants. A similar trend was observed in the second season.

The obtained data in Table (3) clearly show in two growing seasons that, foliar application of antioxidant rates had a simulative effect on chemical constituents of caraway plants. Photosynthetic pigments represented in chlorophyll $\mathrm{a}, \mathrm{b}$ and caroteniods were gradually increased with increasing the rate of ascorbic acid used. The best results were obtained with the medium and high rate (10 and $15 \mathrm{mM}$./L.) of ascorbic acid, with insignificant between them. The increments over the control were recorded 12.20 and $13.24 \%$ for chlorophyll a; 15.68 and $17.11 \%$ for chlorophyll $\mathrm{b}$ and 26.95 and $28.97 \%$ for caroteniods in the first season, respectively, as compared to the untreated plant. A similar trend was observed in the second season, Table (3).

The interaction between the organic fertilization and ascorbic acid treatments was significant in photosynthetic pigments of caraway plants in the two seasons as compared with the control plants. The maximum increase in the studied experiment was obtained by the treatment of $35 \mathrm{~m}^{3} \mathrm{FYM} / \mathrm{fed}$ plus $15 \mathrm{mM}$ ascorbic acid/L, which recorded $26.82 \%$ for chlorophyll a , 37.45 for chlorophyll b and $66.41 \%$ for caroteniods over the control plants in first season. A similar trend was observed in the second season.

\section{2- Nitrogen, phosphorus and potassium concentrations in the herb:-}

Data presented in Table (4) indicated that, caraway plants contained a high concentrations of nitrogen, phosphorus and potassium under farmyard fertilizations as compared to the control plants. Moreover, the mineral elements (NPK) were significantly increased with increasing farmyard fertilizer rates. The maximum increase was obtained from farmyard fertilization at both medium $\left(25 \mathrm{~m}^{3} / \mathrm{fed}\right)$ and highest rates $\left(35 \mathrm{~m}^{3} / \mathrm{fed}\right)$ with insignificant differences between them. The corresponding increase recorded 4.47 and $4.88 \%$ for nitrogen; 4.63 and $5.25 \%$ for phosphorus and 5.76 and $6.36 \%$ for potassium at the first season over the control plants respectively. A similar trend was observed in the second season Tables (4).

Regarding the effect of ascorbic acid, it was clearly show that nitrogen, phosphorus and potassium of caraway plants were also gradually increased by increasing the rates of ascorbic acid. The highest increase was obtained by using 10 and $15 \mathrm{mM} . / \mathrm{L}$, which recorded 7.86 and $8.49 \%$ in for nitrogen ;8.54 and $.49 \%$ for phosphorus and 9.49 and $10.64 \%$ for potassium over control plants in the first season respectively,. A similar trend was observed in the second season Table (4).

The interaction between the organic manure fertilization and ascorbic acid treatments was significant for nitrogen, phosphorus and potassium of caraway plants in the two seasons as compared with the control. The maximum increase in the experiment was obtained by the treatment of $35 \mathrm{~m}^{3} / \mathrm{fed}$ from

Fayoum J. Agric. Res. \& Dev., Vol.22, No.2, July, 2008 
EFFECT OF APPLIED ORGANIC MANURE AND FOLIAR ......

organic manure plus $15 \mathrm{mM} . / \mathrm{L}$. ascorbic acid, which recorded $14.31 \%$ for nitrogen, 15.79 for phosphorus and18.27 for potassium over the control plants respectively in first season. A similar trend was observed in the second season

\section{2- Total carbohydrates, total nitrogen and total protein percentages in fruits:}

Data recorded in Table (4) show that organic fertilization had a simulative effect on total carbohydrates, total nitrogen and total protein percentages in fruits. The best results were obtained with the medium ( 25 $\left.\mathrm{m}^{3} / \mathrm{fed}\right)$ and highest rates $\left(35 \mathrm{~m}^{3} / \mathrm{fed}\right)$ with insignificant differences between them. At the first season these increases recorded 1.71 and $1.91 \%$ for total carbohydrates, 0.32 and $0.41 \%$ for total nitrogen and total protein in fruits over untreated plants respectively. A similar trend was observed in the second season Table (4).

The obtained data in Table (4) show that ascorbic acid application had a simulative effect on total carbohydrates, total nitrogen and total protein in fruits. The best results were obtained with the rates 10 and $15 \mathrm{mM} . / \mathrm{L}$. with insignificant between them. At the first season, these increases recorded 1.10 and $1.22 \%$ for total carbohydrates, 0.55 and $0.59 \%$ for total nitrogen and total protein percentages in fruits over untreated plants respectively. A similar trend was observed in the second season Table (4).

The interaction between the organic manure fertilization and ascorbic acid treatments was significant in total carbohydrates, total nitrogen and total protein percentages in fruits of caraway plants in the two seasons as compared with the control. The maximum increase in the experiment was obtained by the treatment of $35 \mathrm{~m}^{3} /$ fed from organic manure plus $15 \mathrm{mM} / \mathrm{L}$ ascorbic acid, which recorded $3.02 \%$ for total carbohydrates, 0.98 for total nitrogen and total protein percentages in fruits over the control plants in first season. But the four combinations $(\mathrm{M} 2+\mathrm{A} 2$ or $\mathrm{M} 2+\mathrm{A} 3$ or $\mathrm{M} 3+\mathrm{A} 2$ or $\mathrm{M} 3+\mathrm{A} 3)$ were, statistically achieved insignificant differences for total carbohydrates, total nitrogen and total protein percentages in fruits in the first season as clearly indicated in Table (4). A similar trend was observed in the second season.

Fayoum J. Agric. Res. \& Dev., Vol.22, No.2, July, 2008 
Fayoum J. Agric. Res. \& Dev., Vol.22, No.2, July, 2008 


\section{DISCUSSION}

Fertilizing the plants with organic manure resulted in vigorous growth of those as well as highly productivity of fruits with good quality. An increase in each of the measured growth characters (plant height etc....), yields and their component as well as oil production of caraway plants was due to that the application, which fertilizers resulting in more release of available nutrients (micro or macro ones) to be absorbed by the tested plants. It is necessary to refer the physiological roles of these nutrients such as macronutrients (nitrogen, phosphorous and potassium) and micronutrients (Fe, $\mathrm{Mn}, \mathrm{Zn}$ and $\mathrm{Cu}$ ) in plant growth and development. The important role of nitrogen in amino acids, protein, chlorophyll, enzymes and energy transfer substances (ADP and ATP) were early recorded by Russel (1973). Also, the role of phosphorus compounds are of absolute necessity for all living organisms, nucleoproteins constituting the essential substance of the cell and for cell division and development of meristematic tissues (Yagodin, 1982). Moreover, potassium is needed in relatively large amounts by all plants. It aids in the uptake of other nutrients and their movement within the plant. The increasing in growth parameters by organic manure application may be turned to the effect of organic substances on increasing the availability elements and their supply to plants and its effect on the physiological processes such as photosynthesis activity as well as the utilization of carbohydrates. (Beringer, 1978). Mengel and Kirkby (1987) reported that the role of $K$ in metabolism, growth and yield formation can be characterized by two major function : as an activator of enzymes and as $\mathrm{K}^{-}$ions are very mobile within the plant as well as within a cell are transported through biological membranes with high rate and specificity. More than 60 enzymes are known to require $\mathrm{K}^{+}$as an activator. The high mobility of $\mathrm{K}^{+}$on photosynthesis phloem loading and phloem transport...etc. Such three nutrients are among the major essential nutrients needed in large quantities for all plants. They participate directly or indirectly in much important physiological process carried simultaneously within plant cells, tissues and organs differentiation. Micronutrients in sort of fertilizers are necessary because the soil is usually in deficient of them or they are not readily available for plants. The role of $\mathrm{Fe}, \mathrm{Mn}, \mathrm{Zn}$, and $\mathrm{Cu}$ are involved in every metabolic processes such as carbohydrate, protein, growth substances biosynthesis, stomatal movement and translocation of assimilates within the plant were reflected positively on vigorous vegetative growth [Kneel (2002) on Ocimum basilicum L., Matter and El-Yazal (2002) on Damsisa, Youssef et al. (2004) on Ocimum basilicum L., Matter and Mohamed (2001), Agamy et al. (2004) on Calendula officinalis L., and Rady et al. (2005) on Amaryllus plants]. An increase for each of the measured growth characters (plant height etc..) was due to the application of these fertilizers, which resulting in more availability of micronutrients ( $\mathrm{Fe}, \mathrm{Mn}$ and $\mathrm{Zn}$ ) to be absorbed by the recorded plants. The positive action for antioxidants especially, ascorbic acid on growth might be attributed to their effects on counteracting drought, salinity and diseases stresses and protecting plant cells against free radicals that responsible for plant senescence as well as to their auxinic action, and consequently enhancing growth characters (Raskin, 1992 and Elade, 1992). In addition, ascorbic acid might be regulates cell wall expansion, cell division and cell elongation through its action in cell vacuolarization (Arrigoni, 1994; Gonzalez-Reyes et al. 1994 and Navas and Gomez-Diaz, 1995), improves the nutritional status and absorbing phenolic compounds, which lead to save

Fayoum J. Agric. Res. \& Dev., Vol.22, No.2, July, 2008 
the growing tissues from toxic effects of the oxidized phenols (Gupta et al., 1980) and/or enhances the biosynthesis of carbohydrates (Ahmed, 2001) and translocation of sugars (Farag, 1996) which could be explain the present results. These findings are in coincidence with those obtained by Ahmed et al. (1998) and (2003), Tarraf et al. (1999) and Mostafa (2004). In this respect, Al-Qubaie (2002) stated that ascorbic acid as an antioxidant compound has an auxinic action and also synergistic effect on the biosynthesis of carbohydrates and controlling the incidence of most fungi on plants makes them in vigour states and reflects on seed and oil yields. Besides, the induced effect of ascorbic acid as one of vitamins on oil content may be due to that vitamins are recognized to be coenzymes involved in specific biochemical reactions in plants such as oxidative and nonoxidative decarboxylations (Robinson, 1973). Furthermore, Tarraf et al. (1999) reported that an increase in essential oil content of lemongrass was occurred as a result of the foliar spray with ascorbic acid. The results regarding the beneficial effect of ascorbic acid on yield are confirmed with those reported by Ahmed et al. (1998), (2003) and (2004), Hammam et al. (2001) and Mostafa (2004).

Moreover, microelements ( $\mathrm{Zn}, \mathrm{Fe}$ and $\mathrm{Mn}$ ) combined with organic manure also have an improvement effect on vegetative growth parameters. This may be attributed to the essential role of $\mathrm{Zn}$ in synthesis of triptophan amino acid, and consequently formation of auxin, i.e. IAA, which acts as growth regulator especially in prolonging height of plants (Devendra et al. 1999). Also, the favorable effect of the applied treatments on number of branches may be due to its stimulating effect on vegetative growth and physiological processes, i.e. increasing number of cells through cell division and cell elongation and meristematic activity of tissues. The stimulating effect of ascorbic acid on plant growth may be due to its role in transmission of the electron from water to chlorophyll and producing oxygen gas in the photosynthesis, in addition to its role in the nitrogen metabolism through activated nitrite reductase enzyme (Baza, 1984). The beneficial effect of ascorbic acid and organic manure on yield and its components was mainly attributed to its positive action on enhancing growth parameters (Table, 2) and photosynthetic pigments of plants leaves (Table 4). In this respect, Al-Qubaie (2002) stated that antioxidant, especially ascorbic acid, has an auxinic action and also synergistic effect on the biosyntheses of carbohydrate and controlling the incidence of most fungi on plants makes them in vigorous states and consequently reflected on fruit yield. Also, Larson, (1988) reported that, nonenzymic antioxidants play a role in resistance to physiologic disorders caused by oxidative stress. Antioxidant compounds are found in all higher plants, and they include ascorbic acid, $a$-tocopherol, $b$-carotene, glutathione, and other flavonoids. Moreover, the increase in yield and its components by organic manure treatments may be attributed to the metabolic role of $\mathrm{Zn}, \mathrm{Fe}$ and $\mathrm{Mn}$ in organic manure on plant. In this respect, Wilson and Allison (1978) suggested that grain yield may sometimes be limited by photosynthesis (source) and grain (sink) simultaneously and it is possible to increase grain yield by keeping safe the balance between them. The favorable effect of the constituents of organic manure from $\mathrm{Zn}, \mathrm{Fe}$ and $\mathrm{Mn}$ on fruit yield and its components might be attributed to the increase in photosynthetic pigments concentration (Price et al., 1972) as well as enzyme activity, which consequently enhancing plant metabolism (Boardman, 1975). Also, zinc has essential role in carbohydrate metabolism, protein synthesis, triptophan and

Fayoum J. Agric. Res. \& Dev., Vol.22, No.2, July, 2008 
IAA synthesis, since it activates number of enzymes for photosynthesis (Marschner, 1995). The promotive effect of organic manure and ascorbic acid on leaf pigments concentration might be attributed to the enhancing effect of antioxidants and organic manure on the nutritional status of caraway plants, which responsible for accelerating the biosynthesis of various pigments leading to the increase in biosynthesis of sugars. In this respect, the stimulating effect of organic manure on chlorophyll formation and total carbohydrate concentrations were reported by Mohr and Schopfer (1995) who stated that this increase may be due to the enhancing effect of Fe, Mn and $\mathrm{Zn}$ on chlorophyll formation and consequently photosynthesis. In this respect, Price et al. (1972) reported that the basic function of zinc in plant was related to its role in carbohydrates metabolism. The increase in macroelements (N,P, and K) were supported by the results of Ahmed and Abd El-Hameed (2004) who reported that the effect of antioxidants on producing healthy plants leads to enhance the plants to have a great ability for uptake mineral elements. Moreover, Devlin and Withman (1985) reported that, the increase in leaves $\mathrm{N}, \mathrm{P}$ and $\mathrm{K}$ may be due to the effect of $\mathrm{Zn}$ on biosynthesis of auxin (IAA) which promote rooting process and root distribution, and consequently the amounts of mineral elements absorbed by roots and translocated into the different parts of the plant. Also, the use of organic manure led to an increase in root growth and there by higher uptake of macro and micronutrients. The increase in protein content of fruits may be attributed to the increment in total nitrogen percent of leaves and fruits.

Finally, from the present results, it could be concluded that the application of organic manure and/or ascorbic acid greatly increased caraway growth and yield as well as improved fruit quality and its chemical constituents. The content of these substances from elements participate in the different metabolic processes which increased syntheses of chlorophyll, carbohydrates, and absorption of essential nutrients, so that the used organic manure with ascorbic acid could be increase caraway productivity with high quality fruits.

\section{REFERENCES}

Abd El-Hamid, F.; Abd El-Hady, M.; Abd El-Daim. M. and Mahmoud, Y. (1994). Control of seed dormancy of Opuntia (Ficus indica L.). Ann of Agric. Sci., Moshtohor 32 (4):1873-88.

Abd El-Raouf; R.M.S. (2001): Production of sweet basil (Ocimum basilicum L.) in the new reclaimed lands under different levels of biofertilizers and plant density. M.Sc. Thesis Fac. Agric., Ain Shams Univ Egypt.

Agamy, R.A.; Medani, R.A.; El-Yazal, M.A .and Mohamed, S.A. (2004): Effect of some micronutrients on botanical characters and chemical constituents of marigold plant ( calendula officinalis L.). Egypt. J. Appl. Sci.,19 (3B):497-518.

Ahmed, A.M. (2001). Studies for controlling malformation and improving yield and fruit quality of hindy bisinnara mangoes by using active dry yeast, ascorbic acid and sulphur. Minia J. of Agric. Res. \& Develop., 21 (2): 219- 233.

Ahmed, F.F.; Abdalla, A.S. and Sabour, A.M.T. (2003). Growth and fruiting of williams banana as affected by some antioxidant and biofertilizer treatments. Minia J. of Agric. Res. \& Develop., 23 (1): 5168.

Fayoum J. Agric. Res. \& Dev., Vol.22, No.2, July, 2008 
Ahmed, F.F. and Abd El-Hameed, H.M. (2004). Influence of some antioxidants on growth, vine nutritional status, yield and quality of berries in banaty grapevines. Assiut J. of Agric. Sci., 35 (4): 131-140.

Ahmed, F. F.; Darwish, O. H.; Gobara, A. A. and Ali, A. H. (1998). Growth, nutritional status and productivity of Flame seedless grapevine as influenced by the application of citrine and ascobine. Amer. Soc. of Agron. Crops Sci., Soc. of America, Soil Sci., pp. 252.

Al-Qubaie, A.I. (2002). Response of Ficus nitida L. seedlings to the application of some antioxidants under soil salinity conditions. Minia J. of Agric. Res. \& Develop., 22 (3): 235-254.

Aly, M.S. (1999): Effect of FYM alone or combined with NPK on Nigella sativa L. plants. J. Agric. Sci. Mansoura Univ., 24(12): 7567-7577.

A.O.A.C. (1995). Official Methods of Analysis of the Association of Official Agricultural Chemists. Sixteenth ed., Washington D.C., USA.

Arrigoni, O. (1994): Ascorbate system in plant development. J. Bioenerg. Biomembr., $26: 407-419$.

Arulniozhiyan, R. and Pappaiah, M. (1989).Studies on the effect of nitrogen, phosphorus and ascorbic acid on the growth and yield of marigold. South Indian Horticulture,37 (3):169-172.

Baza, M.S.(1984): Effect of some macro and micro elements on growth and yields of maize. M. Sc. Thesis, Fac. Agric. Moshtoher, Zagazig Univ., Egypt.

Beringer, H. (1978): Functions of potassium in plant metabolism with particular reference of yield pp. 185-202. In G. S. Sekhon (ed.) Potassium in soils and crop. New Delhi. India: Potash Res. Institute of India; [ c.f.. Fertilizer Abst. (2), 1981 ].

Boardman, N.K. (1975): Trace-elements in pholosynthesis. In trace elements in Soil- plant Animal System. Edited by Nicholas: 199-212 Academic Press. Inc., New York . San Francisco and London.

Devendar, T.; Najda, C.L. and Tak, D. (1999): Effect of growth regulators on growth and flower yield of tuberouse (Polianthes tuberosa L. ) cv. single. Scientific Hort.(6) 147-150.

Devlin, R.M. and Withman, F.H. (1985): Plant Physiology. $4^{\text {th }}$ Ed. CBS Publishers and Distriibution, 485, Jain Bhawan, Bhola Nath Nagar, Shahdara. Delhi-110 032 ( India ), pp. 443.

Dobariya, M. and Mehta, M. (1995).Effect of irrigation, nitrogen and ascorbic acid on Indian mustard (Brassica juncea L.).Indian Journal of Agronomy, 40 (3): 522-524.

Elade, Y. (1992). The use of antioxidants to control gray mould (Botrytis cineria) and white mould (Sclerotinia sclerotiorum) in various crops. Plant Pathol., 141: 417-426.

El-Fawakhry, M. and El-Tayeb, F. (2003).Effect of som amino acids and vitamins on Chrysanthemum production .J. Adv. Agric. Res., 8(4): 755-766.

El-Gendy, S.A.; Hosni, A. M.; Ahmed, S.S. and Saber, R.M. (2001): Sweet basil (Ocimum basilicum L.) productivity under different organic fertilization and inter-plant spacing levels in a newly reclaimed land in Egypt. Ann. Agric. Sci., Ain Shams Univ., 46 (1): 319-338.

Fayoum J. Agric. Res. \& Dev., Vol.22, No.2, July, 2008 
El-Khayat, M. (2001). Physiological effects of tryptophane, thiamine and ascorbic acid on Hibiscus sabdariffa L. plant. The fifth Arabian Horticulture Conference, Ismailia, Egypt, March 24-28,Vo. 111.

El-Kholy, A. and Salem, M. (1980). Effect of thiamin and ascorbic acid on the yield, essential oil and chamazulene formation in Matricaria chamomilla L. Res. Bulletin, Fac. of Agric., Ain Shams Univ., No.1409, 19 pp.[cf. Hort. Abs. 1981, 51 (8) 6480].

El-Yazal, M.A (2007): Effect of some antioxidants on growth, yield and some chemical composition of onion (Allium cepa L.,) plants. Fayoum J. Agric. Res. \&Dev. 21(1):162-176.

El-Yazal, M.A.; Sawsan, A.S. El-Yazal and Somida. E.G. (2005): Effect of soil application of poultry manure, soil and foliar spray of potassium sources on growth and chemical constituents of Ocimum basilicum L., sweet basil. Egypt J. of Appl. Sci., 20 (12B) : 485- 508.

Farag, K.M. (1996). Use of urea, phenylalanine, thiamine or their combinations to accelerate anthocyanins development and their effect on the storage life of Flame seedless grapes. First Egyptian Hungarian Hort. Conf., Kafr El-Sheikh, Egypt, 15-17 Sept.

Gad, A.M. ; El-Dakhakhny, M. and Hassan, M. M. (1963). Studies on the chemical consitituents of Egyptian Nigella sativa, L. oil. Planta Medical II. 134-138.

Gomes, K.A. and Gomes, A.A. (1983): Statistical Analysis Procedure of Agricultural Research. John Wiley and Sons, New York, pp. 25-30.

Gonzalez-Reyes, J. A.; Alcain, F. J.; Caler, J. A.; Serrano, A.; Cordoba, F. and Navas, P. (1994). Relationship between apoplastic ascorbate regeneration and stimulation of root growth in Allium cepa L. Plant Sci., 100: 23-29.

Gupta, P.K.; Nadgir, A.L.; Macarentias, A.F. and Jagannathan, V. (1980). Tissue culture of forest trees: Clonal multiplication o Tecoma grandis L. (treak) by tissue culture. Plant Sci. Letters, 17: 259-268.

Hammam, M.S.; Abdallah, B.M. and Mohamed, S.G. (2001). The beneficial effects of using ascorbic acid with some micronutrients on yield and fruit quality of hindy bisinnara mango trees. Assiut J. of Agric. Sci.,32 (5):181-193.

Herbert, D.; Phipps, P.J. and Strange, R.F. (1971). Determination of total carbohydrates. Methods in Microbian, 5 (B): 209-244.

Kneel, A.M. (2002)Effect of foliar application with some micro-nutrients on the vegetative growth, volatile oil yield and chemical composition of Ocimum basilicum L., plants .Annals Agric. Sci., Ain Shames Univ., 47(1): 373-387.

Larson, R.A. (1988). The antioxidants of higher plants. Phytochemistry 27: 969-978.

Marschner, H. (1995). Mineral Nutrition of Higher Plant, Second Edition. Academic Press Harcourt Brace and Company, Publishing New York.

Matter, F.M.A. and El-Yazal M.A. (2002): Response of Damsisa plants (Ambrosia mareitima L.,) to foliar spray with some micronutrients. Annals of Agric. Sci., Moshtohor, 40(1): 181-197.

Matter, F.M.A. and Mohamed, S.A. (2001): Botanical studies on Calendula officinalis L. plants as affected by organic and inorganic fertilizers under newly reclaimed soil condition. Fayoum J. Agric. Res. \& Dev., 15 (2): $50-65$.

Fayoum J. Agric. Res. \& Dev., Vol.22, No.2, July, 2008 
Matter, F.M.A. and Somida, E.G. (2006): Effect of propagation methods and organic fertilization on growth and chemical constituents of Ocimum basilicum L., sweet basil. Fayoum J. Agric. Res. \& Dev., 20 (2): 66-85.

Mengel, K. and Kirkby, E.A. (1982):" Principles of Plant Narration. $3^{\text {rd }}$ Publisher International Potash Institute, Worbalaufen- Bern /Switzerland, pp, 593 - 655.

Mohamed, S.A. (2006): A comparison between the effect of different sources of organic and mineral fertilizers on growth, anatomical structure, yield and chemical composition of roselle (Hibiscus sabdariffia L.) plants. The Second Conference on Farm Integrated Pest Management 16-18 Jan. 2006, pp. 99-111 , Fac. Agric., Fayoum Univ Egypt .

Mohamed, S.A. and Matter, F.M.A. (2001): Effect of ammonium nitrate and organic fertilizers on growth, volatile oil yield and chemical constituents of marigold (Tagetes minuta L.) plant. Fayoum J. Agric., Res. \& Dev., 15 (1): 95-107.

Mohr, H. and Schopfer, P. (1995): Plant Physiology Translated by Gudrum and Lawlor, D.W. Spring- Verlag, Berlin Heidelberg, New York.

Mostafa, E. A. M. (2004). Effect of spraying with ascorbic acid, vitamin B and active dry yeast on growth, flowering, leaf mineral status, yield and fruit quality of Grand nain banana plants. Annals Agric. Sci., Ain Shams Univ., Cairo, 49 (2): 643-659.

Navas, P. and Gomez-Diaz, C. (1995). Ascorbate free radical and its role in growth control. Protoplasm, 184: 8-13.

Page, A.I.; Miller, R.H. and Keeny, D.R. (1982). Methods of Soi Analysis. Part II Chemical and Microbiological Methods. $2^{\text {nd }}$ Ed. Amer. Soc. Agron., Madison, Wisconsin, USA.

Price, C.A.; Clark, H.E. and Funkhouser, E.A. (1972): Function of micronutrients in plants. Soil Sci., Soc. of Ameri., 231.

Prusky, D. (1988). The use of antioxidants to delay the onset of anthracnose and stem end decay in avocado fruits after harvest. Plant Disease, 72: 381-384.

Rady, M.M.; Ebtsam, M. Abdella and Hassanain, M.A. (2005): Effect of soil-N application and foliar nutrition with $\mathrm{Zn}$ and $\mathrm{Mn}$ on growth, flowering and keeping quality of amaryllis plants (Hippeastrum vittatum, herb) Fayoum J. Agric. Res. \& Dev. 19 (2): 79-96.

Rady, M.M. (2006): Efficiency of growth and productivity of sunflower plants as affected by ascorbic acid under saline reclaimed soil conditions. The Second Conference on Farm Integrated Pest Management, 16-18 Jan.186-200.

Rai, P. (1997). Effect of ascorbic acid on seedling growth of Bauhinia purpurea Linn. Van- Vigyan., 35(1): 1-4.

Raskin, I. (1992): Salicylate, a new plant hormone. Plant Physiol., (99): 799803.

Reda, F.; Fadl, M.; Abdel-All, R. and El-Moursi, A. (1977). Physiological studies on Ammi visnaga $\mathrm{L}$. The effect of thiamine and ascorbic acid on growth and chromone yield. Egypt. J. Pharm. Sci., 18: 19-27.

Robinson, F.A. (1973): Vitamins. "Phytochemistry", Vol. III: 195-198. Lawrence P. Miller (Ed.), Van-Nostrand Reinhold Co., New York. 
EFFECT OF APPLIED ORGANIC MANURE AND FOLIAR ......

Russel, F.W. (1973): Soil condition and plant growth. Language Book Soc. Longman. London, pp. $30-37$.

Somida, E.G. (2002): Effect of organic manure, nitrogen and potassium fertilization on growth, flowering and chemical constituents of marigold plants (Tagetes minuta L.,) Ph.D. Thesis, Fac. Agric., at Fayuom, Cairo Univ., Egypt.

Taha, A.M.A. (2005). Effect of concentration and application methods of ascorbic acid, thiamine and tryptophane on the growth of tuberose plants. M. Sc. Thesis, Fac. Agric., Alexandria Univ.

Tarraf, S. A.; Gamal El-Din, K. M. and Balbaa, L. K. (1999). The response of vegetative growth, essential oil of lemongrass (Cymbopogon citratus Hort.) to foliar application of ascorbic acid, nicotinamide and some micronutrients. Arab Univ. J. Agric. Sci., Ain Shams Univ., Cairo, 7(1): 247-261.

Welburn, A.R. and Lichtenthaler, H. (1984): Formula and program to determine total caroteniods and chlorophyll $\mathrm{a}$ and $\mathrm{b}$ of leaf extracts different solvents In Advances in Photosynthesis Research (Sybesma C.Ed.) Vol., II pp. 9- 12.Mortinus Njihoff Dr.W. Junk Publishers, the Hague

Wilde, S.A.; Corey, R.B.; Lyer, J.J. and Voigt, G.K. (1985): Soil and Plant Analysis For Tree Culture. $3^{\text {rd }}$ Ed. Oxford IBLT Publishing Co., New Delhi: 9-100.

Wilson, J.H. and Allison, J.C. (1978): Production and distribution of dry matter in maize following changes in plant population after flowering Ann. Appl. Bio (1): 90-121

Yagodin, B.A. (1982). Agricultural Chemical. Part 1. Mir. Publishers, Moscow, USSR.

Youssef, A.A.; Mona, Y. Khalil and Abou Zaid, E.N. (2004): Response of Ocimum basilicum L., to foliar application of kinetin and cheated iron .Annals Agric., Sci., Ani Shams Univ., 49(1): 287-298.

Zhang, S. and Klessing, D.F. (1997): Salicylic acid activites a 48-KOMAP Kinase in tobacco. plant Physiol., (9):409-824.

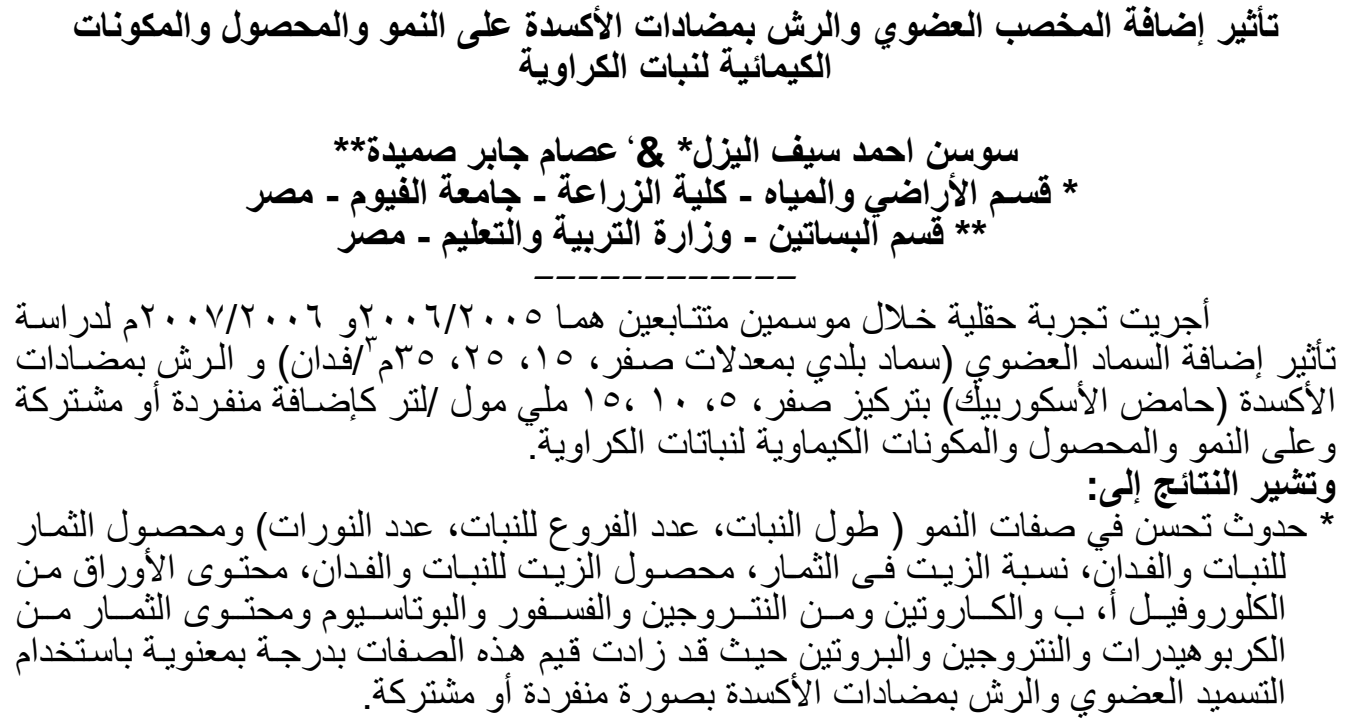

Fayoum J. Agric. Res. \& Dev., Vol.22, No.2, July, 2008 


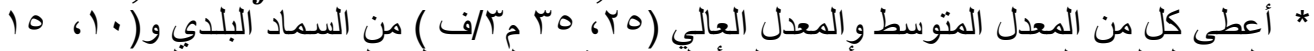

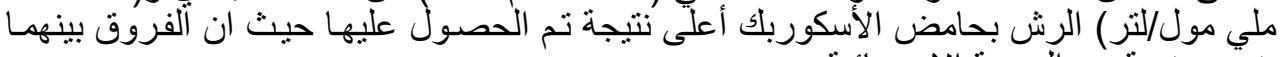

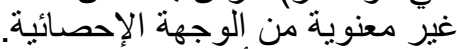

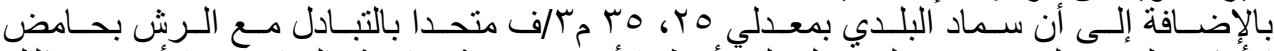

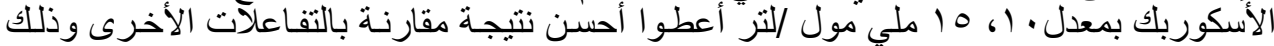
لعدم وجود فرق معنوي من الوجة الإنه الإحصائية.

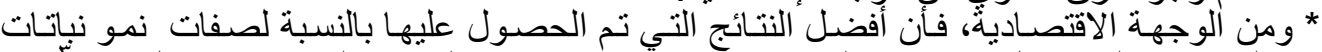

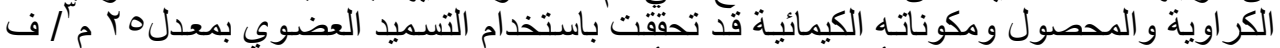

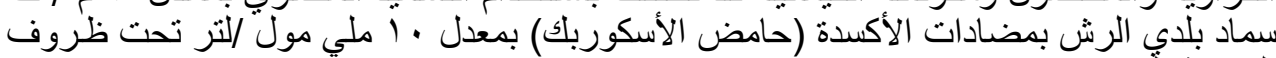
التجربة التي تم إجر ائها. 